\title{
"TECHNOLOGY OF USING E-LEARNING MODELING PROGRAMS IN TEACHING SPECIAL SUBJECTS IN PROFESSIONAL EDUCATION"
}

\author{
${ }^{1}$ Xolmuxamedov Murodullo Maxmudovich, ${ }^{1}$ Jamolov Anvar Kuchkorovich ${ }^{2}$ Xo'jjiyev Mamurjon \\ Yangiboyevich, ${ }^{2}$ Savriyeva Iqbol Bahodirovna ${ }^{3}$ Olimov Sodiq Anvar o'g'li \\ ${ }^{1}$ Institute of Pedagogical Innovation, Retraining and Advanced Training of Leading and Pedagogical Personnel of Professional \\ Education, Uzbekistan. ${ }^{2}$ Bukhara Engineering Technological Institute, Bukhara, Uzbekistan. ${ }^{3}$ Scientific researcher, Bukhara \\ Engineering Technological Institute, Bukhara, Uzbekistan. E-mail: aaanvarovich@gmail.com
}

\begin{abstract}
:
Nowadays, the focus on education is to radically reform professional education, that is, to develop e-learning tools based on the concept of learning outcomes. A distinctive feature of the cognitive-visual approach to the development of electronic didactics is the concentration of attention through visual support, as the formation of visual models of objects studied taking into account human psychophysiology and demonstration of practical skills of learners, effective organization of the interface with the learning object. Providing feedback on electronic didactic tools, mobile desktop and console platforms, as well as in the browser, based on the principles of design, plays an important role in preparing future engineers for professional activities. Therefore, interactive software was developed through the cognitive visualization of a simple oil distillation laboratory. This virtual learning lab was developed using the Microsoft Visual Studio software package. This, in turn, provides a certain degree of convenience in the introduction of electronic didactic tools in engineering education.
\end{abstract}

Keywords:

Electronic didactic tools, cognitive visual approach, logical semantic model, virtual laboratory, 3D max, Adobe Flash.

Article Received: 18 October 2020, Revised: 3 November 2020, Accepted: 24 December 2020

\section{INTRODUCTION}

The constant changes in the education system of Uzbekistan require the introduction of new tasks for modernization. Information and learning environments and e-learning systems [1, 2]. Modernization education is aimed not only at changing the content of disciplines, but also at improving them, expanding the methodological and technical base, increasing student activity in the process and cognitive-visualization of all disciplines in the technical field. Information and telecommunication technologies are technologically feasible. It opens the door to new opportunities for supporting the learning process, providing access to a variety of information sources, and for the student's active participation in the learning process. Innovative environment requires increasing and using the information environment of the professional learning environment. Modern textbooks require the gradual transition to a digital learning platform [3].

Many studies show that seeing about $80 \%$ of the information a person receives, the process of perceiving visual information, the more expressive the image, the more expressive the visual, the better the visual information seen, will be remembered for a long time [4-6]. This will make it possible to create very realistic threedimensional models of computerized development graphics, i.e. modeling programs, in digital education.

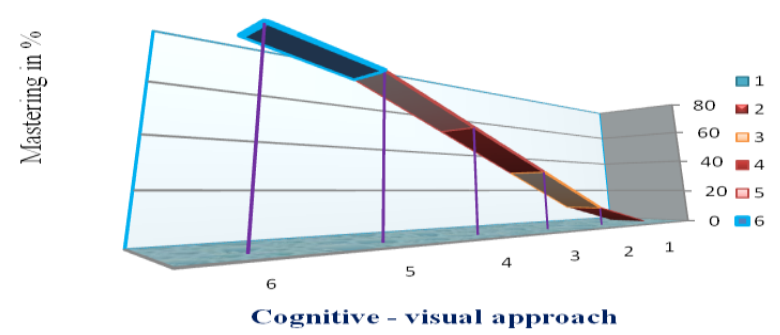

Figure 1: Diagram of the level of visualmemory 
Such models are an effective tool for learning materials. Traditional teaching methods increase the level of vision and comprehension. However, the concept of 'appearance' that students already have is an image, a specific model of objects in the subject area associated with the display of their image, which implies a passive perception of this information. Thus, N.N. Manko states that "on the one hand, the development and manifestation of individual and personal characteristics of subjective importance are human qualities. On the other hand, the traditional form of reproductive activity continues to dominate." Cognitive visualization allows us to shift attention from one visual function to another, learning to develop cognitive skills and critical thinking is an effective type of cognitive activity.

This study sought to develop materials with a new level of visualization based on the concept of cognitive visualization based on an information technology platform that complements the development of e-didactics.

\section{Design of electronic didactic tools with cognitive visualization}

Based on the analysis, we will consider the following principles in the design of electronic teaching aids.

i. Development of educational materials, learning outcomes and development planning. It is necessary to divide into modules that represent the learning material, to enrich logically filled blocks of teaching materials, as well as teaching aids and guidelines, to ensure that the intended purpose is to achieve the specified didactic goals . The modular development approach provides electronic didactic tools with flexibility and variability of the curriculum, creates a favorable environment for students to work independently with the proposed material, and realism at a pace that is convenient for them. When choosing the presentation of e-learning material, you should pay attention to the motivation of students to interact with learning materials, their willingness to define its purpose (form) (universal learning actions, learning outcomes), place of use and stable feedback in time study.

ii. Customize the learning process. The learning process needs to be specific, with a structure that meets the learning needs of a particular student.

iii. Use interactive forms of interaction with the learner. Interaction in e-learning materials should be aimed at the formation and development of an individual's cognitive structures in an active manner. Allows you to implement an interactive program. Learning through movement: students not only see the learning material, but also interact with it, walk with it, reflect on it, gain new experiences.

Numerous studies have shown that the quality of mastery in the use of learning materials improves the quality of training of active cognitive activity professionals in different teaching methods that involve different types of participants in the learning process $[8,9]$. The transition to a competent approach and practical skills in training requires the use of professional tasks, interactive forms and methods. Interactive teaching methods speed up the learning process, allowing students to understand, master and apply knowledge in solving practical problems. Effectiveness is the average use of knowledge that not only enrolls students but also engages them more actively in the admissions process. Interactive learning increases motivation and activity, the ability of participants to solve the problems discussed, which gives an emotional impetus to subsequent events. The search activity of the participants motivates them to take concrete actions, the learning process becomes more meaningful [10, $15,17]$. This allows for effective person-centered learning.

Part of cognitive activity is not only visualfigurative, but also abstract logical thinking [11, 18 , 19]. It is proposed to develop interactive programs to give a special role to cognitive methods of visual enhancement of students' cognitive abilities during development. The choice of the concept of cognitive visualization depended on the following factors: 
i. When visualization is used in teaching, the effectiveness of learning the material increases, not only the visual but also the cognitive function;

ii. The development of didactic tools that take into account the psychophysiological features of visual information allows the human mind to make the most rational and successful use of opportunities;

iii. due to its ability to present a large amount of information in a concentrated form, there is an activation of educational activities that is convenient and sufficient for human psychophysiology [7].

\section{The following different methods of visual structure are used in teaching practice}

block diagrams, graphs, reference signals, logicalsemantic models, meta-plans, etc.: the amount of knowledge provided, the complexity of working with them, the level of detail of subject concepts, etc.

This differentiation of cognitive visualization tools allows them to be introduced into education. Activities taking into account pedagogical tasks. The development of electronic teaching aids seems very promising. V.E. The specific features of the didactic multidimensional technology proposed by Steinberg are determined and included by the characteristics of the subject area. Special organization of the training material and easy presentation, as well as software to form and support the necessary educational activities. One of the main tools is this multidimensional didactic technology, which is a "logical-semantic model that combines two components: the semantic component is represented by a system of concepts related to logical meaning. and the semantic connections between them "[12].

Logical-semantic models can be used both in the acquisition of new material and in generalization to reflect what allows students to understand the level of mastery of the material studied. Their use is to develop modeling skills, build knowledge, analyze objects by identifying properties, synthesize by filling in missing components, systematize based zation, compare and conclude based on concepts, establish cause-and-effect relationships, and more. [12]. Logical-semantic models in the model are not given in a ready form, it is possible to fill in individual coordinates (nodes) independently, as well as to create logicalsemantic models that allow deep understanding and mastering of independently studied material. . Assessment of the level of mastery of the studied topic can also be used in the development of assessment tools for cognitive imaging techniques [13].

\section{An example of model implementation}

Using the developed interactive example, let's look at some of the suggested principles of "Simple Oil Driving Lab" software with cognitive visualization (Flash Adobe). The interactive training program introduces students to the principles of the process from the transition of the oil in the flask from liquid to vapor to the production of a second new product.

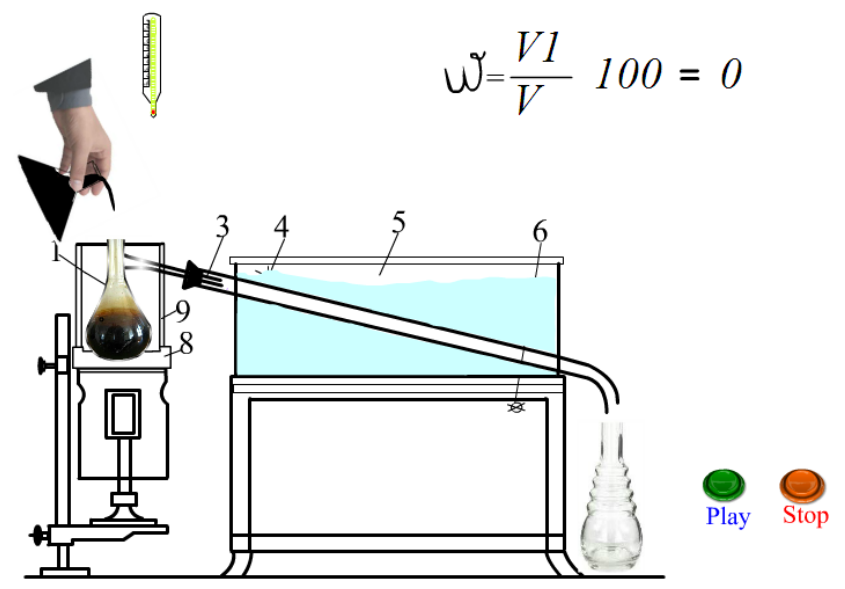

Figure 1: (a) Laboratory diagram of a simple oil pump

As the process takes place, students pay great attention to design, as the teacher must work carefully and attentively in the programming process on the structure of colors and equipment given to every detail.

During the primary normal driving process, the color of the oil should not differ from the real oil, because the student's work in relation to reality always causes insecurity, and self-confidence can lead to suspicion. It takes a great deal of knowledge and skill on the part of a teacher to prevent this from happening.

Objects are given a regulatory function, thereby activating learning actions, supporting reflex 
processes, and independent learning cognitive actions [14].

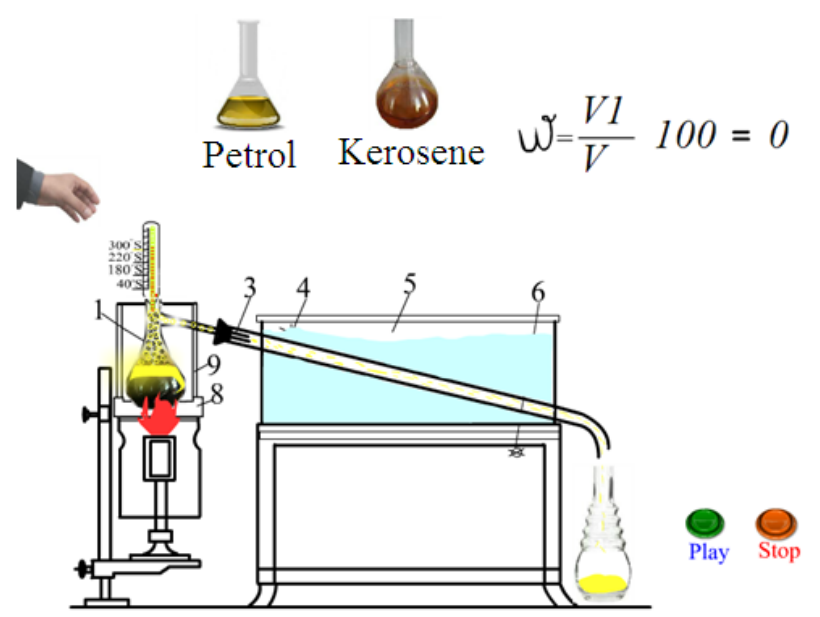

Figure 2: (b) Laboratory diagram of a simple oil pump

Structural logic models for organizing and visualizing learning material. They enable the identification of important connections between the elements of the object under study, the synthesis of a holistic system of elements of knowledge, the creative thinking methods and technologies required by experts at the current pace of scientific and technical development to contribute to the formation and development of products. An example of a logical-systematic model (Figure 3).

\section{Working with the study material includes the}

\section{following steps:}

i. Working with the study material includes the following steps:

ii. stage - the object of emotional and sensory experience of images of external characters under study;

iii. stage - to determine the properties of the object, to establish connections between the elements;

iv. stage - to determine the functional relationships in the structure of the object;

v. stage - to perform specific actions with a known object;

vi. stage - examination and evaluation of educational activities.

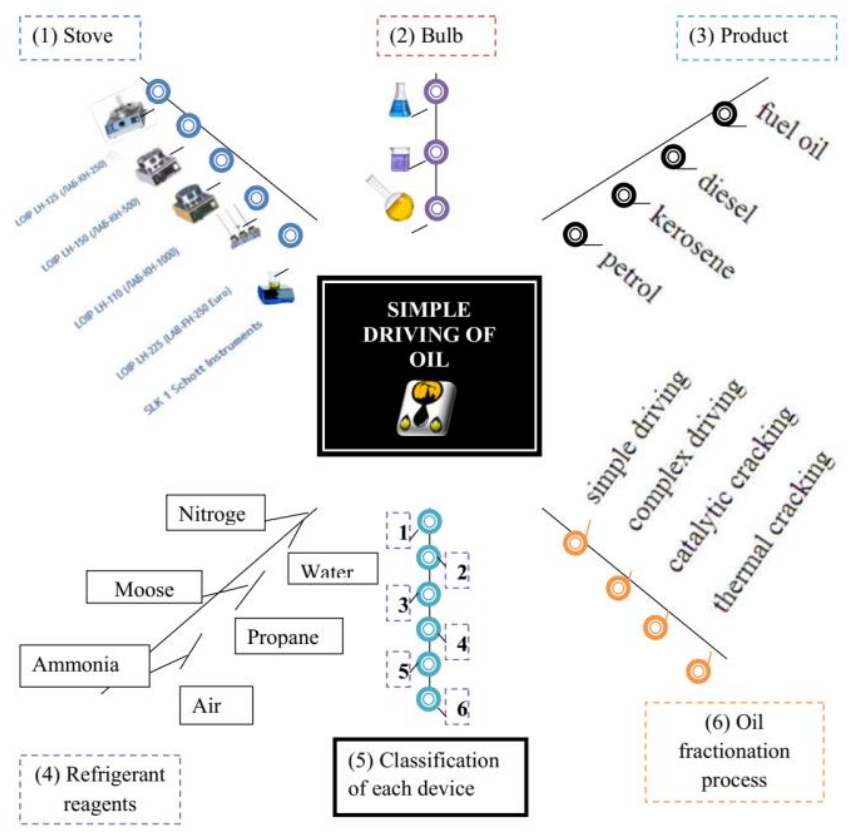

Figure-3. Logical-systematic model of

"Conventional oil distillation laboratory"

The program provides an interactive threedimensional model of the fractionation of oil in the laboratory, the learner sees not only the model. It has the ability to interact with it (controls the appearance of the object, the speed of the mechanism. To monitor the operation of process mechanisms, there are commands in $3 \mathrm{D}$ max or Adobe Flash computer programs to move slowly or steadily. shown. 3, a, b, c.

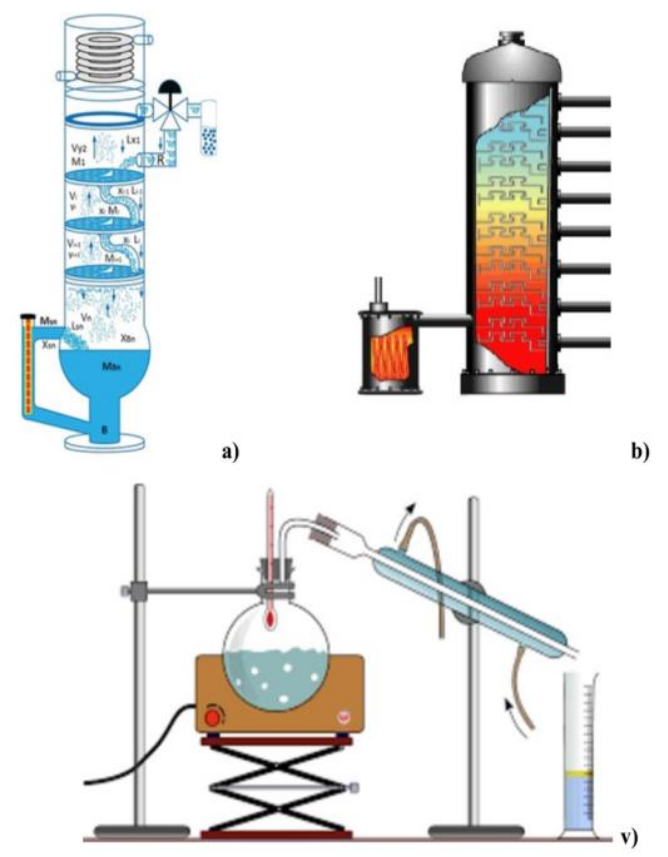

Figure-4. Visualization of laboratory and rectification processes in oil refining technology. $(a, b, v)$ 
Interactively, students can edit, for example, software formulas to calculate the results in the laboratory. Students have the opportunity to determine the share of goods in each product.

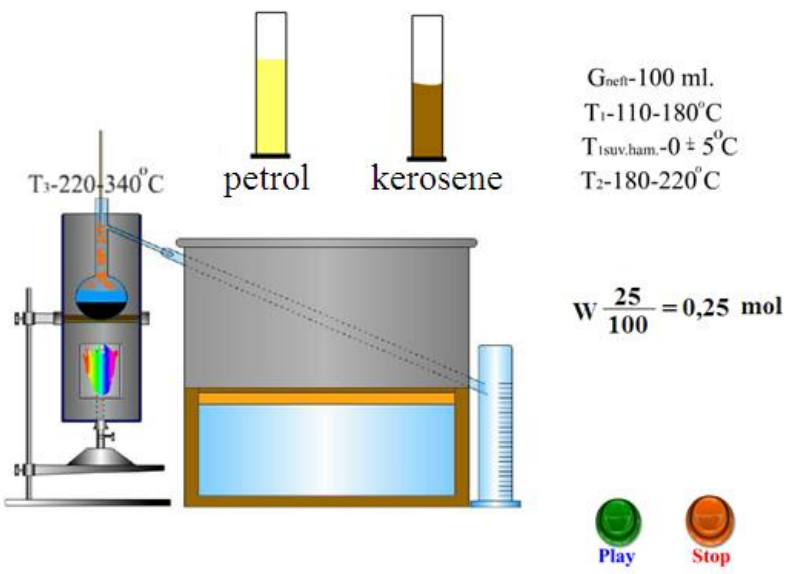

Figure-5. Scheme for calculating the value of the product in the laboratory

In selecting the software development tools for the above application, we took into account the following criteria: cross-platform; mobile device access to learning materials; browser support; display speed. Technical solutions for the presentation of electronic graphic data after analysis of the variety, the selected Unity software mechanism. Unity software laboratory is very popular among 3D developers.

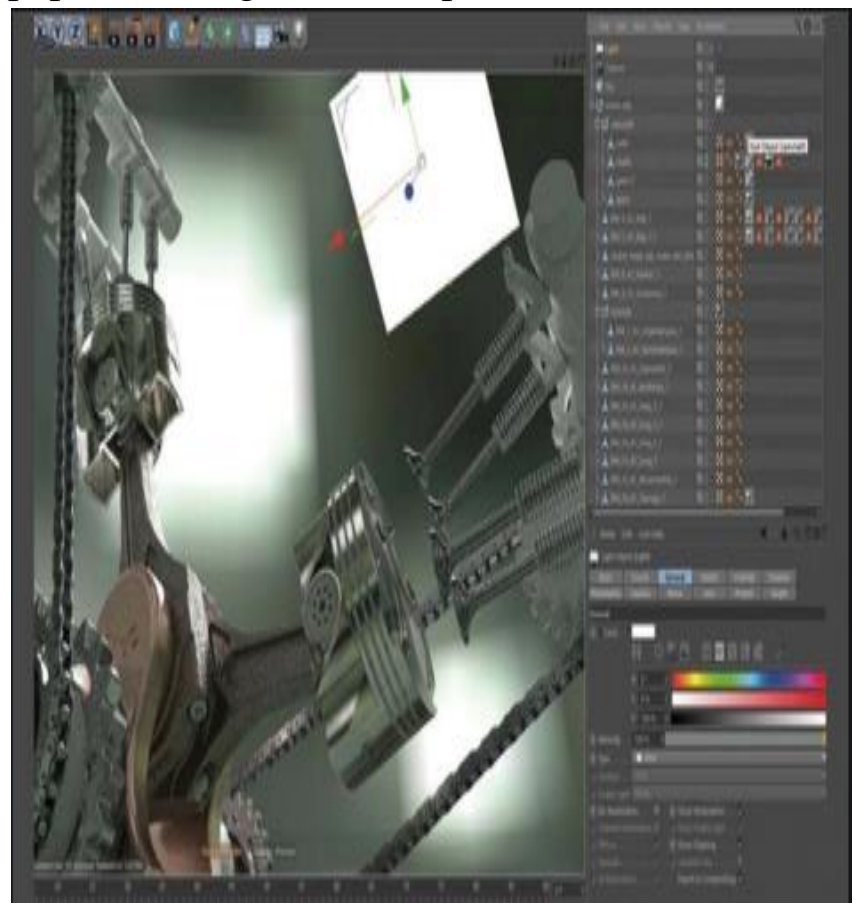

Figure-6. Piston diagram drawn in 3D max (a)

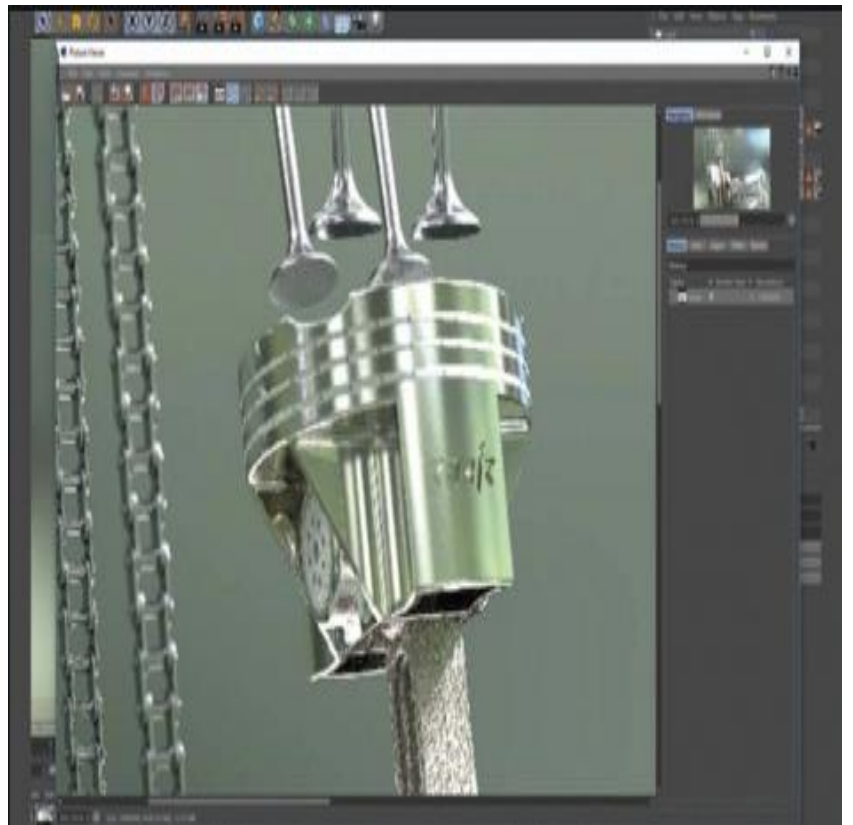

Figure-7. Piston diagram drawn in 3D max (b)

Allows you to create programs that describe complex processes. Three-dimensional graphics are widely used in scientific research, engineering design, construction of computer models of physical objects. Three-dimensional graphics is one of the most complex and comprehensive areas of computer graphics. A user working with 3D graphics should have knowledge in areas such as design, lighting, moving objects and cameras, and using sound and display effects. Here you will find information about the founders of the industry - space, object modeling, demonstration. In recent years, traditional $3 \mathrm{D}$ modeling, threedimensional 3D modeling, animation, and demonstration programs have become more common. Discreet's 3D Studio MAX or Alias Wavefront's JAVA are hybrid graphics packages developed in this period. Because they allow you to work with $2 \mathrm{D}$ and $3 \mathrm{D}$ vector objects on the one hand, on the other hand, the result of the work is a pixel image - taken as a separate frame or on video tape [20, 21, 22, 23].

Features of 3D modeling and the ability to add animation to them dramatically increase their interest:

i. show effects in the film and video industry;

ii. television in commerce (advertising);

iii. in interactive games;

iv. in art and architectural design (decoration); 
v. at demonstrations of oil and gas technologies and equipment;

vi. tutorials and can be used on a computer.

One of the main advantages of the laboratory is that it supports many platforms: Windows, OS X, Windows Phone, Android, Apple iOS, Linux and others. Thus, it is enough to create a single package of the program and place it on all major mobile, desktop and model platforms, as well as on websites $[15,16]$.

\section{The structure of the developed program} (Figure-8).

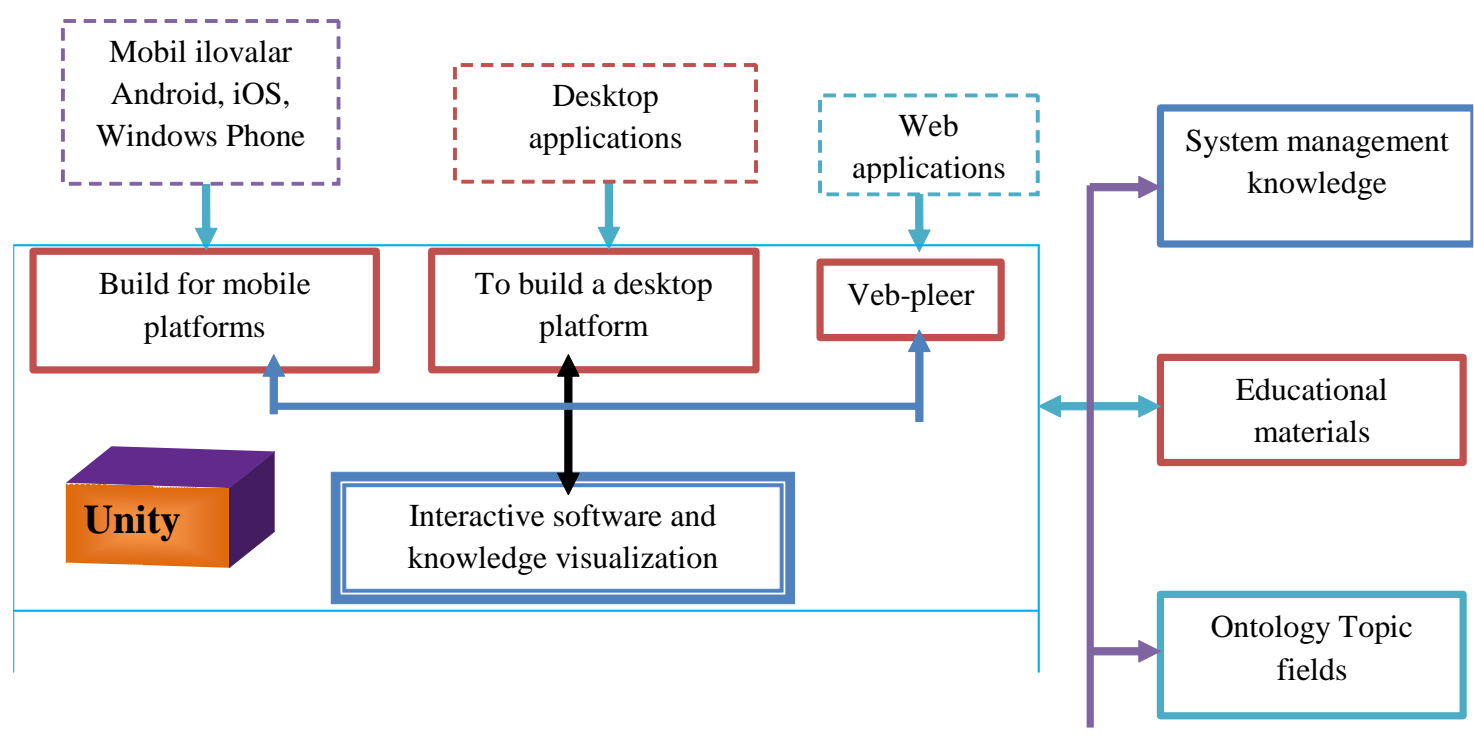

Figure-8. Schematic of the software structure of the control of the animation laboratory using the program Allway.Sync-19.1.5

necessary skills in teaching.

\section{CONCLUSION}

The following main results were obtained during the research:

This article discusses the transition from didactic tools that contribute to the development of cognitive abilities and critical thinking to an effective type of mental thinking, cognitive activity; He justified the relevance of the use of cognitive-visual means in the context of integration. In the development of e-didactics, an interactive program with cognitive visualization in e-learning has been developed, which takes into account the possibility of using the laboratory using Allway.Sync, the modernization of information and learning environments and systems.

Based on the above, it can be assumed that the use of the interactive method is aimed at improving the learning process and the formation of the

Visualization allows the student to form a twoway trajectory in decision-making when analyzing learning outcomes and developing solutions for managing individuals to explore the possibilities of applying further developmental approaches.

It should be noted that some aspects of the results obtained in this article are reflected in the experience of developed countries, as well as the innovative aspects of the achievements and achievements of leading countries in education and production. Of course, today's global opportunities require opportunities for mutual knowledge and exchange of ideas.

As a result of the research, the following methodological recommendations were developed:

i. It is necessary to expand the opportunities for e-learning and education in every subject; 
ii. Digitization of general and specialized disciplines in terms of meaning and content is expedient;

iii. The organization of gymnasium rooms for specialty subjects at the faculty level is a modern requirement.

\section{REFERENCES}

[1] Olimov Q.T., Nazimova F.R., Alimov A.A. Personality oriented and activity oriented techniques in lifelong professional education. Lifelong learning. Continuous Education For sustainable development. Proceedings of the 10 th Anniversary International Cooperation. Volume 10. Part II. Saint-Petersburg-2012. 199-201 6.

[2] Олимов К.Т., Сайфуллаева Д.А. Подготовка, образование и профессиональная подготовка молодых людей с инвалидностью на основе инновационных

технологий.Монография.Москва-2020.

[3] Alimov, Azam A., Kakhramon T. Olimov, and Alisher KhGaffarov. "Preparing Future Teachers of Vocational Education for Innovative Activity in Uzbekistan." Eastern European ScientificJournal 2 (2018).

[4] Alimov, Azam A. "Improving the Training the Future Teachers of Special Disciplines in Uzbekistan." Eastern European Scientific Journal 1 (2016): 113-117.

[5] Алимов, Аъзам Анварович. "Совершенствование процесса подготовки будущих преподавателей специальных дисциплин."

Europeanresearch 8 (9) (2015).

[6] Алимов, Анвар Танзилович, Каюм Бешимович Хаджиев, and Аъзам Анварович Алимов. "Применение метода единичных случаев в лабораторном обучении."Молодой ученый 4 (2013): 506-507.

[7] Khamidov Jalil Abdurasulovich, Khujjiev
Mamurjon Yangiboevich, Alimov Azam Anvarovich, Gafforov Alisher Xolmurodovich, Khamidov Odil Abdurasulovich. "OPPORTUNITIES AND RESULTS TO INCREASE THE EFFECTIVENESS OF MULTIMEDIA TEACHING IN HIGHER EDUCATION." Journal of Critical Reviews $7 \quad$ (2020), 89-93. doi:10.31838/jcr.07.14.13

[8] Olimov, K. T., Tulaev, B. R., Khimmataliev, D. O., Daminov, L. O., Bozarov, D. U., \& Tufliyev, E. O. (2020). Interdisciplinary integration-the basis for diagnosis of preparation for professional activity. Solid State Technology, 246-257.

[9] Kakhramon Tanzilovich Olimov, Dustnazar Omonovich Khimmataliev, Sanobar Yuldashevna Ashurova, Feruz Hasanovich Gaffarov, Nozima Nurmukhamadovna Karimova (2020) COMPETENT TRAINING OF FUTURE SPECIALISTS ON THE BASIS OF ACMELOGICAL APPROACH. Journal of Critical Reviews, 7 (15), 24762483. doi:10.31838/jcr.07.15.331

[10] Dustnazar Omonovich Khimmataliev, Muhabbat Fayzievna Khakimova, Jalil Abdurasulovich Khamidov, Ranazhan Matyakubovna Abdullaeva, Lazizbek Olimovich Daminov (2020) IMPROVING THE PROFESSIONAL COMPETENCE $\mathrm{OF}$ PROFESSIONAL

TEACHERS. Journal of Critical Reviews, $7 \quad(11), \quad 1131$ 1137. doi:10.31838/jcr.07.11.196

[11] Хамидов, Ж. А., \& Ахмедов, Э. Р. (2019). НЕКОТОРЫЕ АСПЕКТЫ ОРГАЗАЦИИ ИНФОРМАЦИОННООБРАЗОВАТЕЛЬНОЙ СРЕДЫ В ПРОФЕССИОНАЛЬНОМ ОБРАЗОВАНИИ.

In ИННОВАЦИОННЫЕ ПОДХОДЫ В СОВРЕМЕННОЙ НАУКЕ (рp. 76-82).

[12] Асқаров, И. Б. (2017). Бўлажак касб таълими ўқитувчиларида 
тадқиқотчилик

кўникмаларини

шакллантиришнинг замонавий масалалари. Современное образование (Узбекистан), (4).

[13] Алимов, А. А., Тоиров, Б. Б., \& Савриева, И. Б. (2020). УМУМКАСБИЙ ФАНЛАРНИ ЎКИТИШ ЖАРАЁНИНИ ТАШКИЛ ЭТИШ ВА БАХОЛАШ. Science and Education, 1(8), 199-206.

[14] Алимов, А. А. (2012). Технология обучения, ориентированная на деятельность. Молодой ученый, (2), 243-246.

[15] Abdurasulovich, K. J., Anvarovich, A. A., Mamatkulovich, Y. U., Yangiboevich, K., \& Sobirovna, M. M. (2020). THE ADVANTAGES OF THE METHODOLOGY OF PREPARING STUDENTS FOR INNOVATIVE ACTIVITY ON THE BASIS OF VISUAL TEACHING OF SPECIAL DISCIPLINES. Journal of Critical Reviews, 7(14), 1244-1251.

[16] Khamidov Jalil Abdurasulovich, Khujjiev Mamurjon Yangiboevich, Alimov Azam Anvarovich, Gafforov Alisher Xolmurodovich, Khamidov Odil Abdurasulovich (2020) OPPORTUNITIES AND RESULTS TO INCREASE THE EFFECTIVENESS OF MULTIMEDIA TEACHING IN HIGHER EDUCATION. Journal of Critical Reviews, 7 (14), 8993. doi:10.31838/jcr.07.14.13

[17] Хўжжиев, М. Я. (2020). ВОЗМОЖНОСТИ ПОВЫШЕНИЯ ЭФФЕКТИВНОСТИ МУЛЬТИМЕДИА В ПРОЦЕССЕ УРОКА.Universum: психология и образование, (1 (67)).

[18] Хужжиев, М. Я. (2016). Очистка и осушка газов растворами гликолей. Наука и образование сегодня, (3), 33-34.

[19] Хужжиев, М. Я. (2016). Изучение процесса риформинга и подготовки нефтепродукта. Наука и образование сегодня, (3 (4)).

[20] Хужжиев, М. Я., \& Хайдаров, Г. А. У. (2016). Изучение характеристики физических поглотителей для очистки газов.Наука и образование сегодня, (3 (4)).

[21] Хужжиев, М. Я., \& Нуралиев, С. С. У. (2016). Очистка газов водными растворами метилдиэтаноламина. Наука и образование сегодня, (3 (4)).

[22] Хужжиев, М. Я. (2016). Материалы и реагенты для приготовления промывочных растворов в нефтехимической отрасли. Наука и образование сегодня, (3 (4)).

[23] SadriddinFayzullaevich, F., Arashovich, M. B., Boboqulovich, T. B., \& Anvarovich, A. A. (2020). Development of technologies for producing catalystfor destructive hydrogenization of asphalt-free oil of heavy sulfur oil. Journal of Critical Reviews, 7(14), 75-80.

[24] Тоиров, Б. Б., Хамидов, Ё. Ё., \& Асадова, 3. А. (2019). ИННОВАЦИОННЫЕ ТЕХНОЛОГИИ ОБУЧЕНИЯ. ВЕСТНИК МАГИСТРАТУРЫ, (5-3), 117.

[25] Ismatov, N. A., Radjabova, V. E., \& Toirov, B. B. (1999). Biochemical and consumers qualities of sorgo flour.UZBEKSKII KHIMICHESKII ZHURNAL, (5/6), 82-83.

\section{Internet resources}

[1] https://www.htbook.ru/kompjutery_i_seti/ dizajn_i_grafika/3d-modelirovanie-vautocad

[2] https://udesign.uz/?gclid=EAIaIQobChMIq3s0oib7gIVCKCaCh1xZAtQEAEYASA AEgItWPD_BwE

[3] http://bookash.pro/ru/s/\%D0\%9F\%D1\%80 $\% \mathrm{D} 0 \% \mathrm{BE} \% \mathrm{D} 0 \% \mathrm{~B} 3 \% \mathrm{D} 1 \% 80 \% \mathrm{D} 0 \% \mathrm{~B} 0 \%$ D0\%BC\%D0\%BC\%D0\%BD\%D0\%BE\% 
D0\%B5+\%D0\%BE\%D0\%B1\%D0\%B5\%

D1\%81\%D0\%BF\%D0\%B5\%D1\%87\%D0

$\% \mathrm{~B} 5 \% \mathrm{D} 0 \% \mathrm{BD} \% \mathrm{D} 0 \% \mathrm{~B} 8 \% \mathrm{D} 0 \% \mathrm{~B} 5 /$ 